\title{
STUDENTS' STRUCTURAL AND CULTURAL PROBLEMS IN TRANSLATING FROM INDONESIAN INTO ENGLISH
}

\author{
Bahrul Ulum \\ Universitas Islam Balitar, Blitar, East Java Indonesia \\ Email: bahrululum@gmail.com
}

\begin{abstract}
Abstrak
This study is aimed at evaluating the lexical, grammatical and cultural problems faced by students of translation subjects in translating from Indonesian into English. The subjects of this study were students with low average ability. The findings show that students have problems in translating lexical, grammatical and cultural items. Based on the results of the analysis, it can be concluded that the problems are caused by low mastery of lexis, grammar and culture. It is recommended that the lecturers of translations give attention to these three aspects.
\end{abstract}

Keywords: Translation, lexis, grammar, culture.

Received: 10 June, 2016; Accepted: 8 September, 2016

\section{INTRODUCTION}

Almost each nation has its own language which is usually different from languages of others. Since the relation between one nation and the others should always be maintained, a communication should also be done from time to time. Such a communication between nation in this globalization era may be done by all components such as scientists, philoshopers, politicians, educators, and the like. The communication cannot be done effectively because of different languages. In solving the linguistic hindrance due to the different languages, translation, as a way of communication, may be employed (Newmark, 1988). In short, translation functions as a bridge in communication among different nation in the world.

In order to translate well, a translator needs specific abilities. Skykes (1983) states that the translator should recognize words and their characteristics as lexical units; appreciate the level of style indicated by the choice of particular words, be aware of no equivalent words between languages; understand grammatical structure of the source language and the target language and be familiar with the life where the language is spoken (Pickens, 1983).

Dealing with the target language, he states that the translator should possess abilities in determining proper choice of words, of word order; in gaining knowledge of the type of language appropriate to partcular types of documents and having adequate fluency and correction of expression. In short, a good translator should possess abilities in the source language and the target language.

Moreover, translation is not an easy task to do, because people's thought pattern is partly determined by the structure of the language they are speaking. In other words, languages partly determine the culture-and thought-patterns which known as Sapir-Whorf Hypothesis 
(Kadarisman, 2004). Therefore, the translator should try to find the nearest equivalent in the source language and the target language.

The description above show that producing a good translator is not easy. A great effort should be made to create syllabus, materials, and teaching methods appropriate to the students' need. In order to create them, basic problems encountered by the translation students should be understood. Therefore this present study was focused on investigating the basic problems concerning the lexical, grammatical and cultural items.

\section{METHOD}

The approach adopted was a qualitative one since it was directed toward the determination of the nature of a situation as it exists at the time of the study (Ary, et al, 1979). The design of this study may be categorized into a case study since it studied the translation students of Islamic University of Balitar, Blitar. They represented the low-ability students. Therefore, this study may be applied to students with similar ability.

Three types of data, namely lexical, grammatical and cultural problems were explored. The data were collected through a translation test administered to them. The results of the translation test were carefully read to identify lexical, grammatical and cultural problems. Then the errors were written and coded in a piece of paper. The coded errors were entered into the table. A percentage of errors was calculated. The data were then analyzed by identification of errors, comparison between the source and the target languages and the interpretation.

\section{FINDINGS AND DISCUSSIONS}

The results of data analysis show that the problems encountered by the translation students in translating from Indonesian into English principally can be categorized into three problems namely lexical, grammatical and cultural problems. An additional problem exists. The problem cannot be categorized into the three problems, so it is called miscelaneous problem. Lexical Problems

Lexical problems, which are shown by improper translation and omnision, are distributed into content words and function words. The problems in content words occur in nouns, verbs, adjectives and adverbs. Nouns here consist of abstract and concrete nouns. The problems of abstract nouns are shown by improper translation of circumfix ke-an with adjectives as the base, for example, the word keramaian is translated celebration, entertainment, event, exhibition, fair and soon, instead of festifity. The problems in concrete nouns happen in rendering the words dealing with time, profession, dressing, and kinship. Time in Indonesia is improperly translated, for example sore is translated into evening, instead of afternoon. Profession also causes troubles to the students. The word pedagang, for example, is improperly translated into shoppers and sellers, instead of traders. The students have problems in traaslating pakaian. It is translated into cloth, shirt, t-shirt, or dress. The right translation of pakaian is clothes. The students also find difficulty in rendering something dealing with kinship, the word adik perempuan is just translated into her sister instead of her younger sister. The facts show that the they still have difficulty in rendering terms in Indonesian into those in English due to different concepts existing in English and in Indonesian.

Verbs also cause problems to the students. Verbs may be divided into two categories namely action and non-action verbs. They improperly translate the words kelihatan, melihat, and nampak into look like, watch, and look, respectively instead of seemed, see and seemed. For action words, they have difficulty in translating, for example, mengulurkan in the sentence Keduanya mengeluarkan tangan, bersaaman, into give hands, pay on hands, and pay their hands, 
instead of extended their hands.. These show that contexts play important roles in determining the diction concerning the verbs.

Problems also occur in adjectives. The problems are shown by improper translation in attribute positions. For example the word in the phrase trotoar sempit, is translated into small instead of narrow. In predicative position, improper translation happen, for example for the word penuh in the sentence Trotoar sempit itu semakin kelihatan penuh is variously translated into loaded, heavy and fully.

Beside nouns, verbs, and adjectives, the students also have problems in translating adverbs. The problems are shown by improper ommision translation. For example the word dengan diam-diam are translated into secretly and silently insteadof quietly. Ommision is also shown by the translation of words di situ and di sana.

From the description, it can be stated that the most problematic are verbs, followed by nouns, adverbs, and the last position is occupied by adjectives. The problems in translation are improper rendering and ommisions. Moreover, it can be stated that the improper translation can be caused by several factors. The first is the different structures between Indonesian and English. It can be seen from the fact that each language has its own characteristic. For example, Indonesian and English have different concept about time. Indonesian will say selamat siang at eleven o'clock, but English will say Good morning. The second is the different terms for the same object. There is a certain term in one language that cannot be found in other languages. For example, between Indonesian and English, the word dia in Indonesian is translated as he or she in English because pronoun dia is not inherently characterized by gender. The third is the translator's inadequate vocabulary. The limited vocabulary may result in improper translation or ommision in translation.

The problems in function words happen in determiners, quantifiers, preposistions, and linking verbs. Determiners here consist of articles, demonstrarives and possessives. The problems, principally, are shown by improper translation and ommision. The determiners are improperly translated. For example, the demonstrative itu in the sentence Laki-laki itu adalah suaminya, is translated into a instead of the. The ommisions also happen. The word beberapa tukang jahit itu juga menyewa tempat-tempat di situ is ommited in the translation. Some ommisions also occur in articles a, an and the. Dealing with quantifiers, the problems are shown by improper translation for the word kebanyakan which is translated into those goods, all of them, some of them, and a majority of them. The word beberapa is translated into several and many and timbunan is translated is rendered into a lot of, the hill of most of, some and the supply. The words beberapa, kebanyakan, and timbunan should be translated into some, most and piles of, respectively. Problems in preposition occur in those refrerring to time and place. For example, students improperly translate pada saat itu into in and on that time instead of at that time. Concerning the translation of preposition dealing with place, they translate di lantai into in the floor instead of on the floor. Linking verb be also causes problems to the students. The problems are shown by ommision. For example, in the sentence Kebanyakan pakaian dan batik is translated into Most of them clothes and batik. In the translation, the linking verb does not exist.

The function words here have grammatical functions. Since each language has its own structure, where the grammatical functions may also be different between English and Indonesian, the students tends to transfer the Indonesian into English grammars. As a result, ommisions occur.

Grammatical Problems 
As stated above, the grammatical problems are also given attention in translation from Indonesian into English. In this field, two problems exist, namely morphological and syntactic problems.

In morphology, a problem, namely declination exists. The declination occurs in possessive cases. The problems are shown by ommision and improper word order. The ommision is shown by the fact that the students do not give possessive marker of. For example the phrases emper toko and gong wayang into porch shop and gongs wayang instead of the porch of the shop and gongs of wayang, respectively. The ommision also happen in the possessive marker's, for example Pakaian Pak Mardiya is translated into Pak Mardiya clothes, instead of Pak Mardiyah's clothes. This problem occurs because of different possessive systems between Indonesian and English. In Indonesian, a possessive follows the head word, for example Rumah Tono meaning the house is possessed by Tono. But in English, the possessive construction can be done in two ways namely by adding to the possessor, or using of in front of the possessor. So rumah Tono is equivalent to Tono's house or house of Tono. Though some others use of exist in English.

Syntactic problems in this study appear in modification and in predication. In modification, the problem exists in noun phrases, while in predication, the problems occur in tense, aspect, voice and status.

Modification serves to broaden, qualify, select, change, describe or even affect the meaning of the head (Nelson, 1958). In this study, the problems mostly occur noun phrases where a noun functions as a head. The problems are shown by improper translation. For example, the noun phrase mesin jahit yang tua dan gaduh is variously translated into old sewing machine and so crowded, old sewing machine which makes noise, etc. instead of the old and noise sewing machine. The translations the students do show that they have difficulty in diction and grammatical construction in the noun phrase in English. Students also have difficulty in finding the proper diction and proper order for certain noun phrase in English, for example they translate musim panen into harvest time, season harvest, and so on instead of harvesting time. It can be said that the problems are caused by the fact that there are some differences in the systems existing in English and in Indonesian. In English, the construction of noun phrase is that a noun head is peceeded by modifier, while in Indonesian, the noun head is followed by the modifier. As a result, Indonesian students are usually confused with the different noun phrases in translating Indonesian into English.

The problems in predication are distributed into tense, aspect, voice and status. Almost all problems are that the students tend to use simple present or present continuous tense when the past tense should be used. For example, they translate the sentence Aku mengikuti ibuku dari belakang dengan diam-diam into I am following my mother . . . and follow my mother instead I followed my mother quietle from hehind. The problem also occurs in using to be. They tend to use present instead of past for example, Laki-laki itu adalah suaminya. Viewed from the context, the past tense should be used, but the students translate the sentence into The man is her husband. Is instead of was is employed in the translation. The problems show that the students still have difficulty in using tense. It can be stated that the problem occurs due to the fact that tenses just exist in English. In Indonesian, no tenses are used,

Aspects in English may be divided into simple, durative, and inchoactive ones. The durative aspect is marked by be $+\mathrm{V}+$ (ing), while inchoactive aspect is marked by get $+\mathrm{V}$ + (ing). The simple aspect is unmarked. In this study, the problems mostly occur in thee durative aspects, namely the ommision of be and the use of other aspects, when the durative aspect should be used. For example, the students translate the sentence Bu Bustaman mengemasi into 
Mrs. Bustaman pack and Mrs. Bustaman packing ... The translations show that there there is an ommision of was and improper translation of pack instead of was packing . . This problem shows that they are still confused with the aspects. In Indonesian, no aspect exists or is grammaticized, but it is just indicated by the word sedang. But in English, such aspect should be taken into account. As a result, Indonesian students may potentially have difficulty in translating sentences containing aspects.

Voices cause various problems to the students. The problems are indicated by ommision of be, improper verb form, and the like. For example, in the clause-sehingga shalat Isya' dilakukannya dengan mengantuk . . . some students translate it into Dzikir after praying Isya done, instead of so Dzikir after praying Isya is done sleepily. In the translation to be (was) is ommited. In the sentence Ningsih masih bercanda dengan adiknya ditemani oleh mbok Siyem, the clause ditemani oleh mbok Siyem is translated into accompany by mbok Siyem instead of accompanied by mbok Siyem. The translations show that they do not consider the verb form and particle. In short, they still have difficulty in rendering voices from Indonesian into English.

Dealing with status, students have problems in negative and interrogative forms. For example, the negative forms are shown by the fact that they improperly translate the form into English. For example in the sentence Aku tidak menyadari telah tiba di depan toko jamu. They improperly translate into I wasn't realize, I am not realize, I didn't realize, instead of I didn't realize that we had arrived in front of the traditional herbal shop. They also have problems in renderring interrogative sentences. For example, for the sentence Dari mana, Jeng? Some students translate it into various ways namely Where Mrs? From where Mrs? Where are you come from? Where come from?. The facts show that they do not have yet considered auxiliary verbs in making negative and interrogative sentences.

In short, dealing with grammatical problems, they cover two areas namely morphological and syntactical problems. The later problems consist of modification and predication. The former problems contains ones in declination, while in predication, ones in tense, voice, status, and aspect.

\section{Cultural Problem} problems.

The problems can be divided into two namely language specific and culture-specific-

The language-specific problems consist of lexicalization, grammaticization, and syntactic patterning. Lexicalization means putting concepts into words. It implies that a certain object may have different names in language. In the lexicalization, the problems are shown by the improper translation made by the students. For example, they improperly translate words dzikir and Jeng into Qur'anic recite, Mrs, respectively instead of dzikir and Jeng. The facts show that they still have problem in lexicalization.

Grammaticization, which means the realization of concepts into grammatical markers, causes problems for the students. This can be shown from the fact that they ommit the particle up showing the position. They translate the sentence Pada saat itulah ia melihat seorang berdiri di hadapannya into At that time, she saw a man standing in front of her. They omit the word up in their translation. In English the article is grammaticized.

Syntactic pattering causes the most trouble for the students compared with grammaticization and lexicalization. English and Indonesian have different syntactic patterning. English can be said to be a subject prominent language. For Indonesian, however, subject may be deleted. The students have problems in this patterning. In translating Mengkhitankan anak laki-laki ... they translate it into Circumcise their sons, without subject, 
instead of They circumcised their sons ... In the translation they neglected the English rule that a sentence should have a subject.

The description shows that the students still have difficulty in translating languagespecific items. Concerning the tendency made by them, the syntactic patterning occupies the highest position, then it is followed by lexicalization and grammaticization,

Cultural-specific problems occur in concrete and abstract objects, specific process or specific concepts and values. The students have problems in translating the words related to concrete-specific objects such as batik, kembang telon, wayang kulit, and gong. They improperly translate them into textile, three kinds of flowers, shadow puppet, and wayang drum, instead of batik, kembang telon, wayang kulit, gong. The specific terms are not necessarily to be translated since they just exist in Indonesia. Abstract objects also cause problems for them. The problem is shown by unnecessary translation, for example, they translate weton into goodday, birthday, celebration, market day. The word weton is not necessarily translated into English since this concept does not exist in English. Beside concrete and abstract-specific objects, cultur-specific process also causes problems. This is shown by unnecessary translation for the word, hajatan into party, event, special prays, intention instead of hajatan. The desciption shows that they still have problems in translating linguistic and cultural items.

The last but not least, beside lexical, grammatical, and cultural problems, the students also have problems called miscellanous problems since the errors are not lexical or grammatical ones or both. They still render the Indonesian words into English without adjusting the grammars. For example, they translate Besok weton kakakku into Tomorrow weton my old brother instead of Tomorrow would be my older sister weton. This kind of translation shows that they still do not understand the nature of translation.

\section{CONCLUSIONS AND SUGGESTION Conclusions}

The words becoming the students' problems are basically the words that are frequently used in English. The students, representing the low-ability students, also had problems in translating the words they are not familar with. Based on the finding, it can be inferred that they still had difficulty, hence problems, in lexis.

In terms of grammatical problems, the data reveal two main areas, morphology and syntax. The conclusion is that the students still had problems in the two areas. In other words, they had deficiency in grammatical knowledge, especially noun phrase and tenses.

The language-specific items and culture-specific items caused problems in translation for these specific population. In language-specific items, syntactic patterning showed the greatest problem, followed by lexicalization. Concerning the culture-specific items, object resulted in problems in transtion, followed by process. Based on the finding, it can be inferred that the students had problems on culturally-bound words. Their problem shows that they had a little number of exposure to culturally-bound words to express specific expression.

\section{Suggestions}

Theoretical and practical suggestions are presented. Theoretically, the translation lecturers focus their attention to teach their students on lexical, grammatical and cultural items in order to improve their knowledge of grammar, lexis and culture. Such an improvement can be obtained by asking them to read more books on the three aspects.

Practically, the suggestions are given to the lecturers, students and other researchers. For lecturers. They should choose materials appropriate to the students' level of knowledge 
about lexis, grammar and culture. They are also suggested to employ the appropriate method in teaching translation. Moreover, they should encourage their students to improve their translation skill in translating by giving models to them. It means that they should be able to show their skills to the students. For students. It is suggested that the students improve their knowledge concerning lexical, grammatical and cultural aspects. Such knowledge may be useful for anticipating problems arising in translation. For other researchers. Other researchers are advised to do similar research with larger population to map out the problem existing in translation. A further research studying the same topic with more variable will be also advisable to see the problems in a more detailed manner.

\section{REFERENCES}

Ary, D. Jacobs, L., and Razavue, C. 2010. Introduction to Research in Education, New York: Hold, Rinehart and Winston.

Francis, W.N. 1985. The Structure of American English. New York. The Ronald Press Company.

Kadarisman, A.E. 2004. Linguistic Relativity, Cultural Relativity, and Foreign Language Teaching. A paper presented at the 52th TEFLIN International Confrennce at Universitas Tridanti, Palembang, 7-9 December 2004.

Newmark, P. 2011. A Textbook of Translation. London: Prentice Hall International Ltd. Picken, C. (Ed.) 2010. The Translator's Handbook. London. ASLIB 